\title{
Development, Balkanism, and new (im)moralities in postsocialist Bosnia-Herzegovina
}

\author{
Federica Tarabusi
}

\begin{abstract}
Despite considerable analysis of development policies in postwar BosniaHerzegovina, local-internationals encounters have received less attention. In an attempt to fill this gap, this article traces the discursive processes through which development professionals frame their narratives about Bosnian society, and in turn, how its inhabitants experience the internationals staying in the country. Applying Maria Todorova's framework, I show how Western "expatriates" tend to incorporate the Balkans' liminality into their social constructs to depoliticize development practices. On the other hand, I approach emic understandings of Europeanness and Balkanism as a situationally embedded and contested process that comes into play to (re)draw social and moral boundaries in Bosnian society. I conclude by considering local-international encounters as a privileged site for exploring the postsocialist state but also new political subjectivities in contemporary Bosnia.
\end{abstract}

Keywords: Balkanism, Bosnia-Herzegovina, Europeanness, internationals

While staying in Sarajevo in 2010, a taxi driver told me that he was happy so many Europeans were coming to his country. With a sneer on his face, he explained how "internationals" brought with them not only a series of serious problems, yet to be resolved in the country, but also a breath of freshness and modernity in a context paralyzed by corruption and inertia. As soon as we got out of the taxi, the Finnish official who had been sitting next to me commented: "Do not believe it as a compliment to us. I know the Balkans, and I could say that any excuse is a good one for pointing out hostility toward one of his fellow citizens... The unity of people here continues to be almost a mirage."
This apparently trivial episode weaving together emic and etic understandings of BosniaHerzegovina ${ }^{1}$ provides a foretaste of the relations between "internationals" and "locals" that constitute a running theme throughout this article.

First, it indicates how deeply the settlement of international institutions, as well as the comings and goings of foreign "expatriates" 3 (stranci in Bosnian), have permeated the cultural intimacy (Herzfeld 1997) of the country and its inhabitants. Such collective perceptions on the part of Bosnian citizens of their cohabitation with "the West" in the local context must not be considered in a vacuum; rather, they are 
historically embedded in broader social and geopolitical processes that make the context of post-Dayton $\mathrm{BiH}$ paradigmatic in many ways (Hayden 2002). As is well known, the interplay between large-scale surveillance by humanitarian organizations (Pandolfi 2000) and development efforts in postwar $\mathrm{BiH}$ has brought many Western professionals to move to, live in, or stay for temporary periods in the country.

More than 20 years after the Dayton agreements, anyone traveling through the region is likely to encounter a series of international offices, institutes, and insignia and run into technicians and diplomats competing over resources with the common goal of "developing" the region. Far from monolithic, the international community includes groups of practitioners with heterogeneous professional profiles: aid administrators and volunteers staying for medium to long periods, development advisors who traipse in and out of the country as if they were tourists, and diplomats visiting for a few days who travel the world in suits and ties. Therefore, internationals constitute a significant social experience for postsocialist $\mathrm{BiH}$ residents: a large percentage of the Bosnians I encountered during my fieldwork had worked-or had friends or relatives who worked-with NGOs or government agencies and had the opportunity to meet Western experts, often perceived as a foreign elite ${ }^{4}$ who drive recognizable cars and frequent international restaurants but also like to sample ćevapčići in a traditional kiosk in Baščaršija (Sarajevo’s Turkish quarter).

At the same time, the notion of internationality has changed over time, evolving from a fixed identity marker to a "category of practices" irrespective of people's actual nationality (Koutková 2016). As part of this shift internationality has become an ever-more popular term for denoting a range of lifestyle, consumption, performance, and social worlds also shared by some locals, such as those working for international agencies (see Baker 2014). However, the blurring of the local-international boundary seems to reinforce, rather than erode, its significance (Stubbs 2016), redrawing forms of exclu- sion and inclusion in the political, social, and economic spaces of contemporary $\mathrm{BiH}$ (Coles 2007). Overcoming the binarism between locals and internationals, this article aims to provide further ethnographic insight into the "black box" of these everyday encounters (Stubbs 2015: 9; see also Jansen 2010).

Second, the above-mentioned anecdote reflects how prevailing normative visions formulated outside Bosnia, "drawn from violence to reconciliation" (Jansen et al. 2016), often inform the parameter through which events in Bosnia are discussed locally. While the taxi driver's words associate Western Europe with modernity and change, the official's comment is based on a widespread perception, common in the Balkans, that casts their peoples as "inclined" to internal rivalries and forced cohabitation. Indeed, the Scandinavian man interpreted the taxi driver's positive comment about Europeans as a way of denigrating his compatriots and tracing lines of division through the local population.

More than two decades since the Dayton Accords, Bosnia continues to bear a common-sense association with interethnic violence and tensions (Hayden 2007; Jansen et al. 2016). The ethnocentric interpretations and mythologies produced in the face of the conflicts in former Yugoslavia have permeated public discourse to such an extent that the term "Balkan" has become synonymous with "chaotic" and "violent." Similarly, in geopolitical jargon Balkanization has not only come to denote the parcelization of large and viable political units, but has also become a synonym for a reversion to the tribal, the backward, the barbarian.

These reductive narratives evoke Maria Todorova's well-known "Balkanism" paradigm (1997). Through a selection of reports by European diplomats, journalists, and academics as well as accounts from popular literature, Todorova has put together a detailed historical reconstruction of the ways certain understandings and images of the Balkans have granted meaning to the ambiguity of this area, framing it as the semi-colonial, semi-civilized, semi-eastern part of Europe: the Other within. This percep- 
tion emphasizes the area's peculiar liminal position and status of incomplete alterity, a part of Europe but also its antithetical periphery:

Thus, ambiguity is treated as anomaly. Because of their indefinable character, persons or phenomena in transitional states, like in marginal ones, are considered dangerous, both being in danger themselves and emanating danger to others. In the face of facts and ideas that cannot be crammed in pre-existing schemata, or which invite more than a single interpretation, one can either blind oneself to the inadequacy of concepts or seriously deal with the fact that some realities elude them. (Todorova 1997: 17)

While other authors including Milica BakićHayden (1995) have considered these assumptions to represent a variant of Orientalist discourse (Said 1978), Todorova instead seeks to demonstrate that "unlike orientalism, which is a discourse about an imputed opposition, Balkanism is a discourse about an imputed ambiguity" (1997: 17).

More recently, some scholars have invited us to bring a postcolonial perspective to bear on our understanding of postsocialist experiences and contexts that were not formally colonies (Chari and Verdery 2009); examples include humanitarian missions in ex-Yugoslavia, forms of largescale surveillance targeting multi-protectorates (Hayden 2002; Pandolfi 2000), and the distinctive regulatory trajectories of "post-socialist neoliberalisation" embedded in international efforts (Jansen et al. 2016). Adopting this lens, Tanja Petrović has pointed out (2013) how contemporary political hierarchies in Europe conceal a framework of discursive constructions of the Balkans as a "Colonial Other." The dynamics of eastward EU enlargement and the unequal mobility of Balkan citizens in this territory display indeed the tropes of a colonialist and paternalistic discourse that indefinitely casts the Western Balkans ${ }^{6}$ as Europe's semi-periphery in need of "saving." Therefore, these countries corralled into a "waiting room" are promised inclusion in Europe as soon as they Europeanize, and thus de-Balkanize, themselves (Kolstø 2016).

Against the grain of official discourses, ethnographers have launched a reflexive emic engagement with the everyday experiences of postsocialist societies, shaped by particular global historical conjunctures (Jansen et al. 2016; see also Lofranco and Pusceddu 2017). Challenging the normative view imposed by core EU members, such research has explored a wide range of possible meanings of "Europeanization" in local Balkan cultural and political debates of these countries supposedly comprising the European periphery (T. Petrović 2014). In a similar vein, empirical insights into the categories and procedures deployed by local and global agencies subject ethnocentric discourses to critical scrutiny, paving the way for a new understanding of the social practices, legitimacy, subjectivity, and policies governing $\mathrm{BiH}$ (Jansen et al. 2016).

Building on such ethnographic insights, this article investigates everyday encounters between European development professionals and local residents, especially those working for international agencies, in "mature Dayton BiH." I thus trace the discursive processes Western expatriates employ in constructing the local context and, in turn, the representational forms through which its inhabitants experience Europeans staying in Bosnia. Applying Todorova's framework of Balkanism, the article shows how different ideas of Europe and the Balkans come into play not only in generating asymmetries between international and local actors, but also in negotiating new forms of social organization and belonging in postsocialist Bosnia.

The article is organized as follows. The first section briefly describes the different phases of my data collection to delineate the empirical background. I then examine the ambivalent perceptions of Bosnia expressed by European professionals, highlighting the gap between the inclusivity of official development rhetoric and their actually exclusionary practices. Finally, the last section describes how some Bosnian residents occupying specific $\mathrm{BiH}$ locations de- 
ploy variegated and multifaceted ideas of "Europeanness" and "Balkanism" in peculiar spatial and temporal constellations (Jansen et al. 2016). I conclude by considering international-local boundaries as a privileged site for re-thinking the postsocialist state but also shedding light on new political subjectivities in contemporary Bosnia.

\section{Fieldwork}

This article's ethnographic foundation mainly comprises data collected from 2005 to 2012 during repeated periods spent in small villages and large urban centers of the Federation of Bosnia and Herzegovina (Mostar, Sarajevo, Bihać, Tuzla, Bašigovci) and the Republika Srpska (Banja Luka, Prijedor, Doboj, Prnjavor). I collected additional empirical material while maintaining long-distance relationships with some Bosnian informants after leaving the field (from 2012 to 2017). This data collection thus took place at different times and in highly diverse fields.

The first phase involved a multisited ethnography of aid conducted between 2004 and 2006 in Italy and Bosnia and aimed at examining the institutional coalitions taking shape among donors, local government, and NGOs as part of an educational project financed by the Italian Ministry of Foreign Affairs and implemented in 41 BiH schools. ${ }^{8}$

A subsequent phase (between 2007 and 2012) included conversations and observation carried out while working as an anthropologist consultant with two development projects promoting cultural tourism in Bosnia. ${ }^{9}$ These projects, a collaboration between the municipalities of Bologna and Tuzla, involved my staying in the region multiple times for periods of about three weeks at a time to supervise project activities.

The most recent research period (from 2012 to 2017) involved ongoing long-distance relationships with some young locals recruited by international agencies as project officers, language intermediaries, and support staff. Belonging to a rather ambiguous social group (Baker 2014; Koutková 2016), local workers have been characterized as both the victims of labor insecurity and an elite that speaks development jargon, travels just as internationals do, and sometimes earns more than state officials (see Sampson 2002; Tarabusi 2011). Building on these observations, the article represents an attempt to look at these local young adults' subjectivities, not necessarily either disadvantaged workers or overprivileged elites.

Thanks to these ethnographic and professional experiences, I was able to build trustbased relationships with some Bosnian citizens as well as the European professionals involved in the formal and informal goings-on of the development projects I was working on or investigating. Methodologically speaking, moving across the interstitial spaces of international development calls for a "polymorphous engagement" (Markowitz 2001). Data were collected from a disparate array of sources including not only participant observation in local project offices but also lunches with consultants, layovers at airports, trips around the area alongside officials and local staff, virtual channels and meetings via Skype, telephone, or email.

Nevertheless, working on local/international relations requires the ethnographer to reflexively consider her own position as part of a transnational community (Mosse 2013). Indeed, the field is dotted with fluid, situated representations of anthropologist-consultants who move back and forth across local-international boundaries. As Karla Koutková (2016) has also shown, Bosnian co-workers might perceive ethnographers as nasa (one of us) by virtue of their own emic experience of the context even while seeing them as stranci (foreigners) in other circumstances by virtue of their national affiliations. However, it was precisely by playing on the ambiguity of my positions that I was able to find common ground with various interlocutors occupying asymmetrical positions in the political arena.

\section{When developers encounter Balkan(ism)}

Much of my time spent with European professionals working in Bosnia revealed how the 
discourses informally circulating among internationals often tend to incorporate commonplace stereotypes about the Balkans. It is quite common to find such narratives expressing the idea that interethnic tensions and native corruption practices represent a foregone obstacle to processes of "democratization." These assumptions are not always particularly understated. During a lunch in Mostar, a British OSCE (Organization for Security and Cooperation in Europe) official argued that working in the Balkans "is not an easy thing to do" because "politicians are corrupt" and local colleagues are "uncooperative." Looking at the other people present, mostly educational program consultants, a Finnish senior manager added that "in countries like Bosnia" it is better to avoid referencing war or politics when speaking with the natives lest we "rekindle old rivalries." The expert, in $\mathrm{BiH}$ for the first time, reached into his bag and pulled out a copy of Balkan Ghosts ${ }^{10}$ and, showing it to his European colleagues, stated: "it says everything worth knowing about the Balkans."

As these narrative fragments suggest, fixed and tribalized visions of the Balkans can serve as the foundations for a discursive strategy of mobilizing and normalizing development practices and, in so doing, "de-politicizing" the effects of such interventions (Ferguson 1994). During the lunch, various stereotypes were deployed to interpret the forms of "dysfunction" plaguing the educational sector, framing problems as part of the "local pedagogical tradition" and deeply rooted corruption characterizing the former Yugoslavian system (Tarabusi 2017). While making these comments, an OSCE consultant turned to a Bosnian "colleague" who worked for the same agency as a linguistic intermediary to say: "and that is why many young people decide to go abroad ... isn't that right, Mahir?"11

Having worked for the OSCE for some time, Mahir was not surprised by these comments. Like other Bosnians, moreover, he often complained ironically about his own country's ineffective aspects, and so he did on this occasion as well. A few days later, however, prompted by my critical comments on what we had heard, he returned to these issues more seriously. During a long journey together to Prijedor, he told me:

Knowing that you know pretty well how this country works ... you will find it amusing how easy it is to capture our strangeness, too. [laughs] The political corruption here is a mess. We agree. We common mortals face a system where, if you don't have connections, private relationships ... you are cut out [...] but I don't think that all this is completely unheard of outside Bosnia, either ... I have worked with European agencies for a long time and I have always seen this stuff.

As noted by Koutková (2016), specific discursive constructions of the Balkans can be useful for maintaining an "ethical dualism" in which internationals' professionalism and networking are seen as essentially different than local practices such as corruption, nepotism, veze (relationships, connections), and štele $e^{12}$ (exchanges and practices through a personalized connection). Questioning this tendency to confound distinct social phenomena, Mahir was concerned with establishing distance between political corruption and those forms of sociality people use to navigate services and negotiate the rights they feel entitled to (Brković 2016). Thanks in part to his contact with internationals, he thus underlined the risks involved in an ethnocentric understanding of $\mathrm{BiH}$ as an eccentric place "frozen" in the remnants of Yugoslavian socialist culture.

However, discourse on the Balkans appeared rather ambivalent. In many cases, comments such as these were alternated with an idealized image of Bosnia as an "ethnic mosaic", a place of perennial pluralism (Donia and Fine 1994), and of the Balkans as a land of "transition," as symbolized by Ivo Andrićs famous bridge. During my fieldwork, I often found aid workers expressing the idea that the Balkans have always been a "crossroads of peoples" and "mix of ethnic groups and religions," as the project manager of an Italian NGO stated during a trip by car to 
Bihać. Therefore, the ethnocentric approach of "semi-colonial" and "semi-civilized" Europe can coexist with essentialist ideas of otherness that cast the liminal nature of the Balkans in an abstract and romantic light (Tarabusi 2017).

Sometimes these ideas are consolidated into actual theories, brimming with a certain romanticism, actors brandish as proof of their sensitivity to "local cultures" and their interest in "native beneficiaries." As Jean-Pierre Olivier de Sardan reminds us, in fact, although developers may come bearing good will, they nonetheless frequently tend to resort to fuzzy concepts borrowed from "bazaar-style anthropology" and "pseudo-sociological notions that bear a closer resemblance to clichés and stereotypes than to analytical tools" (1995: 28). Often featuring terms such as "ethnic mosaic" or "mix of cultures," this do-it-yourself sociology appears to be legitimized by the mere fact of the speaker having been in the field and having interacted, albeit for a short time, with the natives. During a break from work in Bašigovci, for instance, a Spanish aid worker provided her sister, who had come to visit her in the country, with a detailed report on the "customs and traditions of the Bosnians." She regaled her with fascinating stories of their extravagant lifestyles, values based on loyalty and their eating habits, considering the fact that she lived with a family of bošnjaci (the term commonly used to indicate Muslim Bosnians) sufficient to substantiate the authenticity of her pseudo-ethnographic accounts. Satisfied with her understanding of the field, she spent some time painting a picture of a series of customs she considered to be widespread among Muslims (although in reality they have historically been associated with an agricultural and pastoral heritage).

In some cases, these representations by Westerners also draw on the idea of Mirna Bosna (literally: peaceful Bosnia) promoted by local movements known as "Yugonostalgics" who seek to recover an idyllic past marked by Bratsvo $i$ Jedsinstvo (unity and brotherhood). Specifically, some internationals appear to reinterpret certain tropes of "Titoism" through an ethical lens to grant meaning to their presence in the field (in the words of an Italian development worker: "I am here to give Yugoslavia back to Bosnia"). Although this discourse is ostensibly opposed to tribalized images of Bosnia and the Bosnians, it nonetheless reproduces reified ideas about them. The idea of the Balkans as the "semi-Other" inside Europe imbues ideas and knowledge about them with ambiguity: expressions such as "an enigma" and "it is a bit Europe, a bit not" appear repeatedly in the narratives of aid workers.

Nevertheless, their extensive experience in the field can lead some workers to interrogate widespread stereotypes that reduce Bosnia to its ethnic components. Many of my Italian coworkers who spent significant time in the country cited it as an important learning experience, noting that ethnic categories are more a "product" of the conflict than its cause: "if you talk to people about their past, you put together a social map that is not about their ethnic relations ... it was coming from a poor or rich family, from the countryside or the city, that made your life more different" (Francesca, project manager in Tuzla).

By acknowledging the fluid forms of belonging and sociality that run through Bosnian society (see Jansen et al. 2016), such narratives partly mirror ethnographic studies conducted before the conflict. Against common-sense visions, an extensive body of literature has shown that ethnic identifications in the region have always been situationally embedded, based on norms of loyalty and reciprocity (Bringa 1995). In contexts shaped by massive migratory flows from the countryside to the city, ethnic affiliations have historically been connected to even more meaningful forms of identification such as the social categories of urban or rural dwellers. Cornelia Sorabji (1994) made this point in the mid-1980s when challenging certain narratives prevailing in official Yugoslav political terminology, showing that, in daily life, the notion of narod, closely connected to that of komsiluk (neighborhood), was much more multilayered than that of "nation." In this vein, recent studies 
have shown that, in practice, local nationalist projects and international integration policies work to flatten prewar patterns of residence and everyday space of transethnic narod (Hromadžić 2013), thereby disrupting an important "Yugoslav chronotope"13 (Spaskovska 2014).

However, the fact that some development workers are partially aware of the socially constructed nature of ethnicity does not necessarily mean that Bosnians are not encapsulated in reductive representations. As a matter of fact, the rhetoric of national unity fostered by professionals-such as that of restoring "multicultural Bosnia"-often masks a process of differentiation that, in practice, actually acts to exclude this possibility (Coles 2007).

Despite the inclusive populist rhetoric they emphasized, the daily routines of international workers appear characterized by a yawning lack of social networks and relations with their local "neighbors." Although they tend to represent themselves as "cosmopolitan people," during their stay in the country many European aid workers actually seem to prefer events that enshrine a certain localism and feeling of national community. When I was in Sarajevo, I remember some Italian co-workers being puzzled that I would choose to spend time with several Croatian and Bosnian women in Baščaršija instead of accompanying them downtown to watch a series of films by Italian director Federico Fellini. Moreover, most of them admitted that they did not feel "at home" in Bosnia (Carlo, Italian aid administrator) and viewed their time in the country exclusively in terms of developing their curriculum vitae and "professional career," contrasting it with other "human experiences" abroad, for example in Africa or South America (Kirsten, Danish project officer).

Although Europeans and Bosnian citizens often worked at the same aid agency offices and shared a sort of professional intimacy, the life of internationals in Bosnian society is therefore characterized by a certain ambiguity: while they promote inclusive and participatory developmental practices, they keep a part of their private lives confined to a supranational space ${ }^{14}$ that does not overlap with the local social worlds of "their beneficiaries."

\section{European(ess), politika, and new forms of (im)morality}

As I was sometimes perceived as an "international," the questions I posed to young Bosnians working for international agencies were often seen as inappropriate: "Sorry, but I have to get back to work, there is work to be done here ... as you [meaning: internationals] know very well," Zlata told me one day, sarcastically.

My short missions in the field gave me the chance to establish "long-distance" relationships with some of them, however, and to delve more deeply into their everyday social worlds during subsequent stays. Although some Bosnians found it surprising that an "international" would be so interested in spending time with them at a cafe or shopping center, this interest on my part changed their perception of me. While having a drink in Tuzla a few weeks later, Zlata introduced me to her cousin by saying, "This is Federica, Italian by origin but Bosnian by adoption."

Even while maintaining good relationships with foreign colleagues, the local workers sometimes emphasized the distance between themselves and the development policies seen as responsible for fostering a culture of international dependence under the rhetoric of national construction. The dividing line between the immorality of local politicians and the hypocrisy of international actors appeared rather blurry. Commenting on a Sarajevo newspaper, Samir and Zilah expressed irritation at the Constitutional Court's tendency to reproduce the same ethno-national categories it was supposed to prevent: "Nobody trusts politicians or parties anymore. They prostitute themselves and only act in their own interests. I call it mafija ... maybe you, as an Italian, know what I'm talking about! [smiles]"

Far from being produced in a vacuum, such ideas are engendered in a context in which the 
terrain of official politika is a morally debased universe that clashes with the social norms people share and negotiate in everyday life. Concepts of (im)morality and (in)justice do not constitute abstract ideological universes (Delpla 2007); rather, they cut across every sphere of people's social lives and circulate in urban centers through clichés and anecdotes, deeply permeating local cultural debates. Indeed, strongly critical takes on local politics are a daily occurrence. The expression politika je kurva (politics is a whore) has become popular in Bosnia, for example, to express widespread outrage at corrupt and clientelistic practices (Helms 2007), while terms such as foteljasi (armchair politicians) and mafija (cowardice, corruption, and treachery) were coined in the postwar period to condemn the nepotism of political parties and politicians, often associated with the elites who were responsible for the war (Grandits 2007). The term država, on the other hand, is sometimes used indistinctly to denote both the state and the governing party (Helms 2007; Tarabusi 2011). It is quite telling that the leaders of local NGOs make a point of emphasizing their moral integrity and the "apolitical" character of their activities in order to retain credibility (see Sampson 2002).

In this setting, therefore, "morality" comes to constitute a cross-cutting category that is used to judge or denigrate the everyday behavior of individuals and groups. During fieldwork, I noted Bosnian citizens deploying the categories of "corrupt/honest Croatian" and "bad/ good Muslim" in variegated and multifaceted ways to differentiate among individuals belonging to the same national group (Kolind 2008). And yet Bosnian society still harbors a degree of resentment against certain social categories, such as "displaced persons," "refugees," and "war victims," generated directly by the conflict (Bougarel et al. 2007). In some parts of the country, the term lopovi (literally: thieves) is used to express moral indignation about people who took advantage of the conflict to seize a series of benefits (economic, legal, and social) in a highly precarious setting. According to a uni- versity student from Bihać, other local residents who had similarly lost loved ones and suffered during the conflict often viewed such benefits as "privileges" rather than rights. In addition to state subsidies, some victims quickly found jobs, easily obtained positions in the public administration and banded together in local associations that, according to the researcher, often pursue their own personal welfare above all. These critiques of (both local and international) policies should also be understood in relation to the contradictions characterizing the field of state-organized social protection, which often operates through personal relationships and favors (like veze or štele). While the "intrusion" of the sociality of kinship, friendship, and patronage into state arenas has normalized certain local hierarchies (Brković 2016: 17), it has also fueled the condemnation of immoral practices that unequally distribute public benefits and social provisions in Bosnian society.

Ideas of internationality likewise depend on the specific social contexts in which they are situated. In places such as Mostar that have most dramatically symbolized the conflict, locals sought to restore a process of normalization, a state that the "exoticizing" gaze of experts on short-term visits seems to negate (Palmberger 2010). Although local residents did not deny that there are tensions between national groups, they often suggested that internationals contribute to generating disparaging images of their city, images also reinforced by their "local" neighbors at times. During a coffee break at an international meeting in Republika Srpska, Dijana, a co-worker from Mostar, was offended when a local resident asked her: "But what is the situation down there like now?" On our way back to Mostar, Dijana explained: "From Western foreigners you expect stereotypes ... but when even people living in Bosnia can't manage to read history, I can't stand it! The war has been over for almost 20 years and there are still people living in your country who believe that we live in the midst of rubble, ruins!"

The social changes sweeping over urban contexts in the postwar period thus play a key 
role in reshaping local imaginaries and shifting borders/boundaries in the native city (Lofranco 2016). In cities such as Sarajevo, the term stranci (foreigners) might not necessarily be used to refer to Western expatriates; indeed, this word more often refers to groups of fellow Bosnians from a rural background, such as displaced persons, refugees, and repatriates returning to their own cities after the conflict. In this vein, Anders Stefansson (2007) has shown that residents who lived in Sarajevo before the conflict (Sarajlije) do not have a positive view of "newcomers" (dosljaci) and that such forms of identification are deeply rooted in the pre-existing historical tensions between urban residents and rural populations running through the socialist period (Bringa 1995). Sarajlije often complain about the "backwardness" and provincial attitudes of ruralites, thus reproducing the same categorizations that Europeans tend to ascribe to Bosnia and the Balkans (city-dwellers/cultured people/cosmopolitans versus farmers/ backward people/small town dwellers). During a return trip to Sarajevo, a local co-worker made facetious comments about the meeting we had just held at a small, rural village school. Discussing what he defined as the "coarse" behavior of a Bosnian teacher, he jokingly noted that the man's rural background meant he could not be expected "to know all the courtesies chapter and verse."

Unlike contexts in which they are perceived as a hostile population, here internationals embodied values of urbanity and cosmopolitanism (Stefansson 2007) in opposition to styles and features seen as constitutive of Yugoslavia or the Balkans (rural, small-town, backward). While Balkanistic ideas are sometimes rejected, therefore, they may also be internalized to build internal boundaries through "local otherness." As Nicole Lindstrom noted in relation to Slovenia and Croatia, people's own liminal positions can lead to contradictory identity constructions "whereby an insistence on concretizing one's Europeanness coincides with a certain awareness that this European status is never ontologically secure" (2003: 313).
Nevertheless, local/international boundaries become even more ambivalent and blurred in the experiences of young Bosnians employed in international development work. On one hand, they are critical of BiH's exclusion from Europe and the way it traps the country indefinitely in a "waiting room." One day Elvira joked that, since she had relatives who had moved to Germany long before, she could call herself at least partly European. Sead instead expressed his ambivalent relationship with Europe through the metaphor of a gendered entity: "We often say that Europe is like a woman you may want at times, but you don't give in to the temptation because you would regret cheating on your wife." Contesting European policies, Sead framed Europe as something that evokes betrayal, breaking faith with one's family, protection, and loyalty to one's own country.

On the other hand, in opposing ethnocentric ideas of the Balkans these young workers negotiate dynamic meanings of Europe, seen not as rigid membership in a supranational organization (EU) but as a social space embodying new images, aspirations, and subjectivities:

I speak English, you know, I've traveled and with this job I could potentially work abroad ... I don't feel cut off. Maybe on paper ... but I'm not too concerned about BiH's entry into the European Union. ${ }^{15} \mathrm{I}$ don't think it would change my life anyway. Like many of my friends, I feel European because I have desires for myself and for my country. There is no such thing as a Europe, us with our dreams are it. (Elvira, 33 y.o.)

Lots of young people want to leave $\mathrm{BiH}$. I understand, unemployment is high, and there are few opportunities here. But I'm studying economics and trying to gain experience ... the job with EducAid [Italian NGO] is just one ... We shouldn't be running away; we should stay in this country instead, in part to change its image ... not because it lacks problems but because na- 
tionalisms here and politics outside have created a distorted image. My cousin, who was born in Switzerland, recently asked me if I was safe or if the war would be back. She says my aunt and uncle are "worried for us." Worried? I'm the one worried for you, if you as Bosnians think that Bosnia is only corruption, war, and poverty! (Emir, 28 y.o.)

Although working with international agencies was viewed critically, it was also seen as part of a broader social capital that, together with study and travel, might foster the social mobility of a new generation of Bosnians. Against fixed and pre-existing notions of Balkanism, young people such as Elvira and Emir remind us of the multiple ways in which both nationalist elites and European centers can be critically questioned through everyday practices both within and beyond territorial Bosnia.

\section{Conclusion}

Moving beyond the normative post-conflict literature that tends to crystalize Bosnian society in Dayton legal categories (Bougarel et al. 2007), this article aims to provide further ethnographic insight into everyday encounters between locals and internationals.

On one hand, I have traced how some foreign expatriates (stranci) discursively frame their temporary stays in Bosnia, often shaped by a gap between official inclusionary rhetoric and their daily practices of exclusion in relation to the Bosnian state and society (Coles 2007). Applying Todorova's Balkanism framework, I have thus argued that ideas of incomplete otherness within Europe tend to be reflected in Western professionals' ambivalent narratives and experiences in these countries. Along the way, dominant discursive patterns around the liminal status of the Balkans ("the Other within Europe") are differently evoked and manipulated to de-politicize international interventions, rejecting the prewar experiences and space of transethnic narod
(Hromadžić 2013) that are embodied in the Yugoslav chronotope (Spaskovska 2014).

However, fieldwork helps us to capture the ways local actors occupying specific $\mathrm{BiH}$ locations negotiate variegated ideas of internationality and Balkanism within specific spatial and temporal constellations (Jansen et al. 2016). While in conflict-embodying contexts such as Mostar people distancing themselves from the "exoticizing" gaze of international experts, Sarajevo local residents (Sarajlije) tend to employ discourses on Balkanism in reshaping local imaginaries between "natives" and "newcomers" (dosljaci) in relation to pre-existing tensions between urban and rural populations (Bringa 1995). To draw on Nikola Petrović's arguments (2011), societies subject to Balkanization may internalize and renegotiate this imaginary to fuel their own internal demarcations and negotiate their own identities.

Challenging a prescriptive view that would reduce $\mathrm{BiH}$ to its ethnic components, I found that local practices entailed fluid forms of identification in a "mature Dayton $\mathrm{BiH}$ " (Jansen et al. 2016) shaped by economic insecurity, social tensions, and competition over scarce resources (such as housing, work, and education). New terms, such as mafija, foteljasi associated with political corruption and party clientelism, or lopovi to describe people who have benefited from the conflict, express a new, collective "moral order" that takes a critical stance on the structures of the state. In this setting in which politika is an ethically debased universe, concepts of (im)morality and (in)justice are not abstract ideological universes but the everyday experiences of people who often bemoan the loss of the wellbeing and peace of socialist Yugoslavia (a sentiment that also fuels local "Yugonostalgic" movements). In this context, nationalist parties play a key role not only in maintaining social separatism, but also in seeding feelings of insecurity deep within Bosnian society (Bougarel et al. 2007). Moreover, the "intrusion" of kinship, patronage, and personalized connections (such as veze or štele) into state arenas gives rise to inequality in the distribution of welfare provisions 
and social rights (Brković 2016). Consequently, while boundaries and social norms are fluid and dynamic, they are sometimes experienced as rather fixed and inflexible by individuals and groups dealing with the rigid ethnic categorization enforced by state institutions and society (Visser and Bakker 2016).

Local-international encounters are thus a privileged site for exploring the ambiguous relations between the state and its citizens as part of a perennial crisis of sovereignty that has been produced and normalized by development efforts (Pandolfi 2000). Perceived as an "illegitimate predator" (Bougarel et al. 2007) in local narratives, the state is painted as an ambivalent and fragmented space that tends to push people to withdraw into private networks of trusted fellows and morally shared categories.

At the same time, fieldwork invites us to approach the making of locals' own Europeanness as a situationally embedded and contested process. Against prepackaged notions of Europe and the Balkans, local employees of international agencies negotiate dynamic and multifaceted ideas of Europeanness to build on images of social change and mobility across geographic and ideological frontiers (T. Petrović 2014). Beyond representations that would paint them as either victims of precarity or overprivileged elites (Baker 2014; Koutková 2016), local young workers' subjectivities shed light on the ways in which EU-related discourses and policies governing $\mathrm{BiH}$ can be disrupted through everyday practices and counter-discourses that work powerfully against the ethnicization of social life, corruption, and unemployment.

\section{Acknowledgments}

The arguments in this article build on a discussion launched in the book Antonio Maria Pusceddu and Zaira Tiziana Lofranco, eds., Oltre Adriatico e ritorno: Percorsi antropologici tra Italia e Sudest Europa [Beyond the Adriatic and back: Anthropological trajectories between Italy and Southeast Europe] (Milan: Meltemi,
2017), which presents some Italian ethnographic research focused on Southeast Europe. I would like to thank all of the other area scholars I have met over the past few years at seminars and conferences held at universities both in Italy (Bergamo, Bologna, Lecce) and abroad (in particular, Sussex and Maynooth) for their feedback on my research data, part of which I present here. I am also grateful to the NGO EducAid and the Municipality of Bologna for having involved me in a number of development cooperation projects in Bosnia-Herzegovina. I further thank the two anonymous peer reviewers for their rigorous feedback.

Federica Tarabusi is Assistant Professor of Cultural Anthropology at the Department of Education Studies (University of Bologna), where she directs the MA in International Cooperation and Educational Inclusion and sits on the scientific board of the research center on Mobility Diversity and Social Inclusion (MODI). Her research interests include: ethnography of aid in Bosnia-Herzegovina; multicultural policies for immigrants in Italy; ethnic discrimination and gender inequalities; applied anthropology.

ORCID: 0000-0002-8564-909X

Email: federica.tarabusi2@unibo.it

\section{Notes}

1. Hereafter $\mathrm{BiH}$ or Bosnia.

2. I use the terms "internationals" (stranci) and "locals" (lokalci) as emic categories of social identification used in many international agencies in Bosnia. Here, both "internationals" and "developers" are used to indicate professionals working in the complex constellation of agencies channeling large amounts of international development assistance. The second indicates groups of Bosnian residents, variously positioned in society, who are "local" in relation to the "development industry" or the non-local staff members of the organizations they work for. 
3. Interesting works on the knowledge practices of development professionals include: Coles 2007 and Mosse 2013.

4. See Sampson 2002.

5. Against these dominant narratives, critical anthropological perspectives argue that the wellintentioned and morally rooted anti-nationalist positions of most Western observers actually risk distorting the understanding of nationalist conflict as a social phenomenon (Hayden 2007).

6. This political neologism was coined by the EU to refer to Albania and the countries of the former Yugoslavia that entered the EU in 2013, except Slovenia and Croatia.

7. Stef Jansen et al. use this term as an imperfect translation of the term punoljetno (age of majority) to refer first to a spatio-temporal constellation that must be distinguished from the post-conflict era; and, second, to remind scholars to take seriously the fact that the country's conditions have taken shape "in history" within a particular global historical conjuncture, as opposed to the kind of ahistorical and ethnocentric visions that are widely projected onto non-Western countries (2016: 3 ).

8. As part of decentralized cooperation, the project gave me the opportunity to explore how an emerging populist ideological framework of development was concretely translated into aid practices (Tarabusi 2011).

9. Two projects, financed by the Fondazione Cassa di Risparmio di Bologna, were aimed at strengthening the capacities and skills of officials from the Municipality of Tuzla and other local actors involved in promoting tourism and sustainable development of the city.

10. In this well-known book, journalist Robert D. Kaplan (1993) stages a tour of the Balkans to offer up a gallery of macabre scenarios featuring heroes and criminals, corrupt and cynical politicians, gloomy villages, and nationalist passions; in other words, reassuring ethnocentrisms about these unknown regions in the heart of Europe.

11. All personal names in this article are pseudonyms.

12. The word štela is specifically used in $\mathrm{BiH}$ to refer to people, practices, and relations involved in obtaining public or private resources through a personalized connection (see Brković 2016 and Koutková 2016).
13. Ljubica Spaskovska uses this expression to refer to the need to frame Yugoslavian events in an ordinary space-time dimension (2014).

14. Interestingly, Oane Visser and Marte Bakker (2016) observe similar dynamics in the social practices of Sarajevo's young, middle-class adults who tend to center their lives around interethnic and international spaces.

15. In this dialogue that took place in the summer of 2017, Elvira refers to the process of Bosnia applying for membership in the European Union on 15 February 2016.

\section{References}

Baker, Catherine. 2014. "The local workforce of international intervention in the Yugoslav successor states: 'Precariat' or 'projectariat'? Towards an agenda for future research." International Peacekeeping 21 (1): 91-106.

Bakić-Hayden, Milica. 1995. "Nesting orientalisms: The case of former Yugoslavia." Slavic Review 54 (4): 917-931.

Bougarel, Xavier, Elissa Helms, and Duijzings Ger, eds. 2007. The new Bosnian mosaic: Identities, memories and moral claims in a post-war society. London: Ashgate.

Bringa, Tone. 1995. Being muslim the Bosnian way: Identity and community in a central Bosnian village. Princeton, NJ: Princeton Univ. Press.

Brković, Carna. 2016. "Flexibility of Veze/Štele: Negotiating social protection." In Jansen, Brković, and Čelebičić, Negotiating social relations in Bosnia and Herzegovina, 94-108.

Chari, Sharad, and Katherine Verdery. 2009. "Thinking between the posts: Postcolonialism, postsocialism, and ethnography after the Cold War." Comparative Studies in Society and History 51 (1): 6-34.

Coles, Kimberley. 2007. "Ambivalent builders: Europeanization, the production of difference and internationals in Bosnia-Herzegovina." In Bougarel, Helms, and Duijzings, The new Bosnian mosaic, 255-272.

Delpla, Isabelle. 2007. "In the midst of injustice: The ICTY from the perspective of some victim associations." In Bougarel, Helms, and Duijzings, The new Bosnian mosaic, 211-234.

Donia, Robert, and John Fine. 1994. Bosnia and 
Hercegovina: A tradition betrayed. New York: Columbia University Press.

Ferguson, James. 1994. The anti-politics machine: "Development," depolitization and bureaucratic power in Lesotho. Minneapolis: University of Minnesota Press.

Grandits, Hannes. 2007. “The power of armchair politicians: Ethnic loyalty and political factionalism among Herzegovinian Croats." In Bougarel, Helms, and Duijzings, The new Bosnian mosaic, 101-122.

Hayden, Robert M. 2002. "Intolerant sovereignties and 'multi-multi' protectorates: Competition over religious sites and (in)tolerance in the Balkans." In Postsocialism: Ideals, ideologies and practices in Eurasia, ed. Chris M. Hann, 159-180. London: Routledge.

Hayden, Robert M. 2007. "Moral vision and impaired insight: The imagining of other peoples' communities in Bosnia." Current Anthropology 48 (1): 105-131.

Helms, Elissa. 2007. "Politics is a whore? Women, morality and victimhood in post-war BosniaHerzegovina." In Bougarel, Helms, and Duijzings, The new Bosnian mosaic, 235-253.

Herzfeld, Michael. 1997. Cultural intimacy: Social poetics in the nation-state. New York: Routledge.

Hromadžić, Azra. 2013. "Discourses of transethnic narod in postwar Bosnia and Herzegovina." Nationalities Papers 41 (2): 259-275.

Jansen, Stef. 2010. "Of wolves and men: Postwar reconciliation and the gender of inter-national encounters." Focaal 57: 33-49.

Jansen, Stef, Čarna Brković, and Vanja Čelebičić, eds. 2016. Negotiating social relations in Bosnia and Herzegovina: Semiperipheral entanglements. New York: Routledge.

Kaplan, Robert D. 1993. Balkan ghosts: A journey through history. New York: St. Martin Press.

Kolind, Torsten. 2008. Post-war identification: Everyday muslim counterdiscourse in Bosnia Herzegovina. Aarhus: Aarhus University Press.

Kolstø, Pål. 2016. “'Western Balkans' as the new Balkans: Regional names as tools for stigmatisation and exclusion." Europe-Asia Studies 68 (7): 1245-1263.

Koutková, Karla. 2016. “'The king is naked': Internationality, informality and Ko Fol state-Building." In Jansen, Brković, and Čelebičić, Negotiating social relations in Bosnia and Herzegovina, 109-121.
Lindstrom, Nicole. 2003. "Between Europe and the Balkans: Mapping Slovenia and Croatia's 'Return to Europe' in the 1990s." Dialectical Anthropology 27: 313-329.

Lofranco, Z. Tiziana. 2016. "Displaced in the native city: Movement and locality in post-war Sarajevo." In Moving places: Relations, return and belonging, ed. Nataša Gregorić Bon and Jaka Repić, 148-171. Oxford: Berghahn Books.

Lofranco, Z. Tiziana, and Antonio M. Pusceddu, eds. 2017. Oltre Adriatico e ritorno: Percorsi antropologici tra Italia e Sudest Europa [Beyond the Adriatic and back: Anthropological trajectories between Italy and Southeast Europe]. Milan: Meltemi.

Markowitz, Lisa. 2001. "Finding the field: Notes on the ethnography of NGOs." Human Organizations 60 (1): 40-46.

Mosse, David. 2013. Adventures in aidland: The anthropology of professionals in international development. Oxford: Berghahn Books.

Olivier de Sardan, Jean-Pierre. 1995. Anthropologie et développement: Essai en socio-anthropologie du changement social [Anthropology and development: An essay in the socio-anthropology of social change]. Paris: Editions Karthala.

Palmberger, Monika. 2010. "Distancing personal experiences from the collective, discursive tactics among youth in post-war Mostar.' L'Europe in formation 357: 107-124.

Pandolfi, Mariella. 2000. "L'industrie humanitaire: Une souveraineté mouvante et supracoloniale. Réflexion sur l'expérience des Balkans" [The humanitarian industry: A shifting and supracolonial sovereignty. Reflections on the experience of the Balkans]. Multitudes 3: 97-105.

Petrović, Nikola. 2011. "Thinking Europe without thinking: Neo-colonial discourses on and in the Western Balkans." Eurozine, 22 September.

Petrović, Tanja, 2013. "Europe's new colonialism." Belgrade Journal of Media and Communications 2 (4): 107-125.

Petrović, Tanja, ed. 2014. Mirroring Europe: Ideas of Europe and Europeanization in Balkan societies. Leiden: Brill.

Said, Edward W. 1978. Orientalism. New York: Pantheon Books.

Sampson, Steven. 2002. "Weak states, uncivil societies and thousands of NGOs: Western democracy export as benevolent colonialism in the Balkans." In Cultural Boundaries of the Balkans, ed. Sanimir Recic, 27-44. Lund: University Press. 
Sorabji, Cornelia. 1994. "Mixed motives: Islam, nationalism and mevluds in an unstable Yugoslavia." In Muslim women's choices: Religious belief and social reality, ed. Camillia Fawzi El-Sohl and Judy Mabro, 109-127. Providence, RI: Berg.

Spaskovska, Ljubica. 2014. "The Yugoslav chronotope: Histories, memories and the future of Yugoslav studies." In Debating the dissolution of Yugoslavia, ed. Florian Bieber, Armina Galijaš, and Rory Archer, 241-253. London: Ashgate.

Stefansson, Anders. 2007. "Urban exile: Locals, newcomers and the cultural transformation of Sarajevo." In Bougarel, Helms, and Duijzings, The new Bosnian mosaic, 59-77.

Stubbs, Paul. 2015. "Performing reform in South East Europe: Consultancy, translation and flexible agency." In Making policy move: Towards a politics of translation and assemblage, ed. John Clarke, Dave Bainton, Noémi Lendvai, and Paul Stubbs, 65-93. Bristol: Policy Press.

Stubbs, Paul. 2016. "Commentary." In Jansen, Brković, and Čelebičić, Negotiating Social relations in Bosnia and Herzegovina, 122-124.
Tarabusi, Federica. 2011. “Towards an anthropology 'within' development: Educational inclusion and decentralized cooperation in Bosnia Herzegovina." In Disasters, development and humanitarian aid: New challenges for anthropology, ed. Mara Benadusi, Chiara Brambilla, and Bruno Riccio, 151-168. Rimini: Guaraldi.

Tarabusi, Federica. 2017. "Jedna Druga Bosna: Sviluppo, 'internazionali' e prospettive locali in Bosnia-Erzegovina" [Another Bosnia: Development, 'international' and local perspectives in Bosnia and Herzegovina]. In Pusceddu and Lofranco, Oltre Adriatico e ritorno, 153-183.

Todorova, Maria. 1997. Imagining the Balkans. Oxford: Oxford University Press.

Visser, Oane, and Marte Bakker, 2016. "Multicultural vanguard? Sarajevo's interethnic young adults between ethnic categorisation and international spaces." Europe-Asia Studies 68 (2): 460-486. https://doi.org/10.1080/09668136.2015 .1136595 